\title{
Challenges faced by classroom teachers in multigrade classrooms: A case study
}

\author{
Barış Kalender ${ }^{1}$ and Erol Erdem² \\ ${ }^{1}$ Gaziantep University, Turkey (ORCID: 0000-0002-4175-7099) \\ ${ }^{2}$ Ministry of National Education, Turkey (ORCID: 0000-0002-4336-3253)
}

\begin{abstract}
The aim of this study is to identify the main problems that arise in multigrade classrooms. This research was designed as a case study. The data were obtained through interviews and observations. Participants of the study consist of 10 teachers working in multigrade classrooms in a district in the Mediterranean region in Turkey. The data were analyzed by using thematic analysis. As a result of the research, it was found out that the teachers were left alone in the multigrade classrooms and had difficult times. It was determined that they had problems in planning and executing the learning-teaching process, as well as ensuring classroom management. It was also revealed that having the duty of a principal teacher was a heavy burden for teachers and this duty led them to do all kinds of work at schools. It was discovered that the inspections made by the Ministry of National Education did not contribute greatly to teachers. However, parental assistance to teachers in non-educational matters appeared to be the only support for them within their daily workload.
\end{abstract}

Keywords: Multigrade classrooms; Principal teachers; Classrooms teachers

Article History: Submitted 19 April 2021; Revised 23 September 2021; Published online 7 December 2021

\section{Introduction}

Multigrade classroom implementation (MCI) has been described differently by many researchers in the literature. Based on the common aspects of these definitions, the multigrade classroom (MC) implementation can be clarified with the concepts of multigrade classroom, multiage classroom, unified classroom and combined classroom in the literature (Little, 2006). There are many reasons that make MCI compulsory, and these reasons vary by country. Some of the most common reasons worldwide are dispersed settlement, social and economic conditions, geographical features, and difficulty in transportation (Birch \& Lally, 1995; Miller, 1991; Nawab \& Baig, 2011). In addition, it is implemented in order to provide basic education and citizenship education for people living in rural areas (Binbaşığlu, 1999; Köksal, 2005; Little, 2006). Besides, some of the teachers working in such schools have to engage in the administrative duties of the school in addition to their teaching responsibilities. This duty is defined as 'principal teacher' (Kaykanac1, 1993; Özmantar \& Civelek, 2017), for which teachers working in MCI schools have to undertake official duties and responsibilities such as dealing with the maintenance of the school, etc.

Address of Corresponding Author

Barış Kalender, Faculty of Education, Department of Primary Education, Gaziantep University, 27310 Şehitkamil/Gaziantep, Turkey.

$\triangle$ bariskalender27@gmail.com

How to cite: Kalender, B. \& Erdem, E. (2021). Challenges faced by classroom teachers in multigrade classrooms: A case study. Journal of Pedagogical Research, 5(4), 76-91. https:// doi.org/10.33902/JPR.2021473490 
MCI is not only an application specific to underdeveloped and developing countries. In almost every country worldwide, there is an MCI school for similar reasons (Joubert, 2010; Joyce, 2014; Rowley \& Nielsen, 2014) provided above. MCI has a 30\% share in the total number of schools worldwide. Therefore, on average, one out of every three schools has MCI. African continent ranks first with a rate of $50 \%$. In Europe, about half of the schools have MCI, while it is one in every four schools in Scotland, Ireland and England. In the USA, especially in the state of Alabama, such schools are frequently encountered. MCI is also used in Canada, especially in rural areas. In Colombia, approximately half of the primary schools implement MCI (Jordaan \& Joubert, 2014; Psacharopoulos et. al., 1993; Titus, 2004).

Table 1

MCIs in Turkey by years

\begin{tabular}{ccccccc}
\hline Year & $\begin{array}{c}\text { Number of } \\
\text { primary } \\
\text { schools }\end{array}$ & $\begin{array}{c}\text { Number of } \\
\text { students }\end{array}$ & $\begin{array}{c}\text { Number of } \\
\text { MCI }\end{array}$ & $\begin{array}{c}\text { Ratio of MCI } \\
\text { to the total } \\
\text { number of } \\
\text { primary schools }\end{array}$ & $\begin{array}{c}\text { Number of } \\
\text { students in } \\
\text { MCI }\end{array}$ & $\begin{array}{c}\text { Ratio of the number of } \\
\text { students in MCI to the total } \\
\text { number of students }\end{array}$ \\
\hline $2018-2019$ & 24,739 & $5,267,378$ & 7000 & $28,29 \%$ & 135,924 & $2.6 \%$ \\
\hline $2015-2016$ & 26,522 & $5,360,703$ & 7071 & $29.07 \%$ & 156,499 & $2.9 \%$ \\
\hline $2014-2015$ & 27,544 & $5,434,145$ & 8164 & $29.63 \%$ & 186,718 & $3.4 \%$ \\
\hline $2013-2014$ & 28,532 & $5,574,916$ & 8457 & $29.64 \%$ & 214,048 & $3.8 \%$ \\
\hline
\end{tabular}

Note. Workshop Report on the Quality, Problems and Solution Suggestions of Teaching in MC (Provincial Directorate of National Education, 2015). 2018-2019 data were received from KODA Annual Report (Network for Change in Village Schools, 2019)

According to the statistics in Table 1, it is seen that there has been a decreasing trend in the number of MCIs in recent years, as approximately three thousand MCIs have been ceased in the last four years. In addition, the number of students who attend these schools is decreasing each year. At the same time, the ratio of these schools to the total number of primary schools and the proportion of students studying in these schools are decreasing gradually. In spite of the decreasing numbers of MCIs in school systems, there are many reasons that make MCI compulsory in many cases such as when the school systems have no alternative remedy to the service that MCIs provide (Nawab \& Baig, 2011; Rowley \& Nielsen, 2014; Summak et. al., 2011).

According to Table 1, it is seen that the schools with MCI have a share of approximately $30 \%$ in Turkish public-school system. In spite of their weighty representations in Turkish public-school system, only $3 \%$ of the total public-school student population attends schools run by MCI. The first reason for Turkey's case is the basic principles of Turkish National Education, which include equal opportunity and facility in education for all. The main reasons for this situation include population and scattered settlements, lack of buildings and classrooms, lack of residential areas and insufficient number of students.

Due to their structural differences, these schools may have different problems (Little, 2006; Psacharopoulos et al., 1993) such as teachers' dealing with both official duties and teaching, having the responsibility of more than one class (Doğan, 2003), spending more time and energy on planning and preparation (Gözler, 2009), inadequate guidance (Bilir, 2008), etc. In addition to all of these problems, MCI has advantages, as well. These advantages include individual learning, peer learning and group work, which are necessities of such schools. Within MCI classes, some students may develop leadership skills and interact with other students who are younger or older than themselves; also, teachers may develop critical skills while dealing with challenges involved (Gözler, 2009; Şahin, 2010).

As stated above, there are certain advantages and disadvantages of MC for both the teacher and the student in the classroom. However, teachers working in MC have many responsibilities and workload apart from in-class teaching-learning practices. When the relevant literature is examined, it is seen that there are studies on the problems of teachers working in MC. However, it has been seen that these studies generally try to reach a conclusion by collecting data with questionnaires 
and scales or only by interviews (Erdem et al., 2005; Ocakc1 \& Samanc1, 2019; Y1ldız \& Köksal, 2009). However, in this study, in order to reveal the problems of teachers more clearly, comprehensive data were collected through both observation and interviews and it was tried to obtain deeper and more detailed results for these problems. On the other hand, it is thought that trying to obtain a more comprehensive and holistic perspective on the problems that teachers experience by focusing on all their duties in MC adds importance to the research. In this context, it was aimed in this study to determine what sort of problems the classroom teachers working in an MC faced in teaching-learning process in-class and out-of-class and what kind of solutions they offered to solve them. Based on the data obtained, it was aimed to develop suggestions for both policy makers and teachers working in MC. In line with this general purpose, the following questions were intended to be answered:

1- How do classroom teachers working in MC perceive this process?

2- What are the problems faced by classroom teachers working in MC in planning, implementing and evaluating the teaching-learning process? What solutions do they develop to eliminate these problems?

3- What kind of difficulties do classroom teachers working in MC encounter during the out-ofclass process? How do they deal with these problems?

\section{Method}

This qualitative research was designed as a case study. A case study involves an in-depth review of one or more conditions (Patton, 2014), researching a situation in real life, in its current context or environment (Creswell, 2007; Yin, 2009), the factors that affect this situation and in what ways these factors are affected by the situation through a holistic perspective (Cohen et. al., 2005), along with certain decision making and implementation processes. In addition, a concept or a process with similar and different dimensions (Kohn, 1997) requires research in which detailed and indepth information is collected through the use of multiple data collection tools (Creswell, 2007). This research was carried out as a case study, since it aimed to examine the problems faced by classroom teachers working in MC in detail and how they perceived the process.

\subsection{Participants}

The participants of the present study consist of 10 classroom teachers who work in schools with $\mathrm{MC}$ in a district in the Mediterranean region in Turkey. The data were collected from these participants during the spring semester of the 2018-2019 academic year. Participants were selected using snowball sampling and maximum variation sampling methods among other purposeful sampling types. Firstly, a semi-structured interview was conducted with 10 classroom teachers. The teachers to be interviewed were determined by the snowball sampling method. Snowball sampling method is a method used to reach different individuals and groups of the society, or certain groups that deviate from the general behavior of the society (Neuman \& Robson, 2014). Since the district in which this study was conducted was small and there were one or two teachers in each school creating the study group, snowball sampling method was preferred in this study. One teacher who wanted to participate in the study allowed us to contact three different teachers, and those three teachers contacted six other teachers. When more participants could not be found, the study was initiated with 10 participants. Observations were made with six teachers who demonstrated maximum variation in the interviews. Maximum variation was reached by compiling the sample based on teachers' experience in teaching, grade levels that they are teaching, as well as their existing roles in principal teacher's task. A maximum variation sample is collected through the determination of certain individuals in the research in a specific way to provide maximum variation in order to reveal the different dimensions of the problems (Merriam \& Tisdell, 2015). In this study, the highest level of diversity was tried to be ensured by taking into consideration the status of the teachers who would be observe Within the scope of the snowball sampling method, a teacher working in MC was reached and asked for help in finding participants 
who would like to participate in this study. The three participants he found also found the other six participants in the study. When no participant who wanted to participate in the study could be found, the research was carried out with 10 participants and certain factors such as whether they worked as the principal teacher and the grade level of the class they taught. Table 2 displays demographic information about the teachers participating in the interview.

Table 2

Demographics of the participant teachers

\begin{tabular}{cccccccc}
$\begin{array}{c}\text { Teacher } \\
\text { Code }\end{array}$ & Gender & Age & $\begin{array}{c}\text { Year(s) of } \\
\text { Seniority in } \\
\text { Teaching }\end{array}$ & $\begin{array}{c}\text { Principal Teacher } \\
\text { Duty }\end{array}$ & Grade Level & Observed & $\begin{array}{c}\text { Hour(s) of } \\
\text { Observation }\end{array}$ \\
\hline T1 & Female & 23 & 2 & $\mathrm{X}$ & $1-2$ & - & - \\
\hline T2 & Male & 24 & 2 & $\mathrm{X}$ & $3-4$ & $\mathrm{X}$ & 2 \\
\hline T3 & Male & 28 & 6 & $\mathrm{X}$ & $1-2-3$ & $\mathrm{X}$ & 2 \\
\hline T4 & Female & 28 & 7 & - & $3-4$ & $\mathrm{X}$ & 2 \\
\hline T5 & Female & 28 & 7 & - & $3-4$ & - & - \\
\hline T6 & Male & 30 & 9 & - & $1-2$ & $\mathrm{X}$ & 2 \\
\hline T7 & Male & 34 & 10 & $\mathrm{X}$ & $1-2$ & $\mathrm{X}$ & 2 \\
\hline T8 & Female & 35 & 12 & - & $1-2$ & - & - \\
\hline T9 & Male & 38 & 13 & $\mathrm{X}$ & $1-2-3-4$ & $\mathrm{X}$ & 2 \\
\hline T10 & Male & 35 & 16 & $\mathrm{X}$ & $3-4$ & - & - \\
\hline
\end{tabular}

As can be seen in Table 2, the teachers participating in the study have a maximum of 16 years of experience and some teachers have just started their profession. In addition, it is seen that teachers work with four classrooms at most, and most of them work with two classrooms. It is seen that some of the teachers have the duty of principal teacher, while some do not. 6 participants who provide variation were observed for two hours.

\subsection{Data Collection Tools}

\subsubsection{Semi-structured interview}

In this research, a semi-structured interview developed by the researchers was conducted to determine the opinions of the classroom teachers working in the MC and their evaluation of this implementation. The aim of the interview is to examine how the subject of the research is viewed from the perspective of the participants and to reveal the reasons why they have this perspective (Patton, 2014). During the interview, four questions were asked to gather personal information about the participants and six open-ended questions were addressed to evaluate their experiences in the MC. Open-ended questions were reviewed in the literature, and questions that cover all aspects of working in MC were selected. Some questions are as follows: "How do you evaluate teaching in a MC?", How do you think your experiences in MC have contributed to you or what did they take away from you professionally?", "How would you describe your managerial role?". Also, at this stage of data collection, questions were prepared by taking into consideration the opinions of two classroom teachers working in $\mathrm{MC}$ and two doctoral students studying on classroom teaching. The interview guide took its final form after gathering the opinions of a faculty member working in the Department of Classroom Teaching at Çukurova University.

\subsubsection{Observation}

At the second stage of the research, observation was used, which is one of the qualitative data collection tools. Observation is an activity for gathering data, performed to obtain first-hand information about a person, a situation, event, fact, concept, object or condition (Ciesielska et al., 2018). In this study, researchers were in the role of non-participant observers. In non-participant observation, researchers make observations without interfering with the observation environment 
or the people who are observed (Patton, 2014). An observation form was prepared considering the dimensions of semi-structured interview and the findings obtained from the interviews. In this form, four topics discussed in the interview were addressed (principal teacher's duty, teachinglearning process, classroom management, activities apart from the educational processes). The process was also recorded with a voice recorder while filling in the observation form. Accordingly, teachers working in schools with MC were observed in two lessons and two break times at school. Observations were carried out in order to observe teachers' in and out-of-class activities. Before starting the observations, teachers were contacted and schools were checked for observation on appropriate days and class hours. Some teachers asked the researchers to come in for the last two lessons of the day for observation. In this case, when the researchers realized that the teachers were staying late at the school after the classes were over, the observation continued during this period. In this study, six teachers were observed among the interviewed teachers on a voluntary basis.

\subsection{Data Collection}

The data collection procedure started with the first teacher working in an MC school. Based on the participant selection method, which is the snowball sampling method with a special attention given to the maximum variation, other $\mathrm{MC}$ teachers were defined and interviewed one by one. The participant teachers were first interviewed, and then 6 of them were observed in their classrooms. First of all, the researchers collected the data through semi-structured interviews by meeting faceto-face with 10 participant teachers. As a result of the data obtained from this interview, a semistructured observation form was prepared and six teachers, who would provide maximum variation, from the participant group were observed by the researchers.

\subsection{Data Analysis}

The data obtained from the interviews and observations were analyzed using thematic analysis method. Thematic analysis is a data analysis method used to identify, analyze and report patterns in data. It is used to present the data obtained from the research to the readers as organized and interpreted. With this analysis method the data is arranged in the smallest dimensions and provides rich and in-depth descriptions (Braun \& Clarke, 2014). In this study, the themes were determined in advance through the semi-structured interview and observation forms. The sources of the predefined themes and codes were mainly the relevant literature and the research questions. The themes used to organize and run the data analysis were Assessing Being a Teacher in MC, Evaluation of Teaching-Learning Process, Evaluation of Principal Teacher Task, School Facilities, Relations with Out-of-School Actors.

\subsection{Validity and Reliability}

In qualitative research, four concepts are taken into account instead of validity and reliability. These are credibility, transferability, dependability and conformability (Lincoln \& Guba, 1985). To begin with, some strategies are used to ensure credibility. These are presenting information about the characteristics of the participants (Johnson \& Christensen, 2004), ensuring that the research has been reviewed by a field expert (Merriam \& Tisdell, 2015), and receiving the approval of the participants about the findings obtained from the analysis (Patton, 2014). In order to ensure credibility in the current research, detailed information was provided about the participants, the information was presented to a faculty member in the field, in line with whose suggestions necessary arrangements were made, and lastly, it was enabled that the results obtained from the research were confirmed by participants. As another concept to consider, transferability can be achieved by providing detailed information about all dimensions of the research (Merriam \& Tisdell, 2015) and by directly giving place to the participants' statements (Lincoln \& Guba, 1985) so that the readers can benefit from the research findings in their own situation. In this context, in order to ensure the transferability of the research, the research process is presented in detail; moreover, direct quotations from the participants representing the codes revealed in the 
presentation of the findings are also included. Thereafter, in order to ensure dependability of the research, coder or researcher reliability was used. For this aim, both researchers coded the data independently, and then compared their findings. At this point, coder reliability was revealed using Miles and Huberman's (1994) [Reliability: Consensus / (Consensus + Disagreement)] formula. In accordance with this formula, coder reliability was found to be .81. For situations where disagreement occurred, the researchers discussed their thoughts to seek agreements on these issues. Finally, so as to ensure the conformability of the research, it can be enabled that the reader has the opportunity to compare the interpretation of the data obtained from the participants with the direct citations of the participants and accordingly will have the opportunity to test the power of the interpretations and whether these interpretations represent the citations (Silverman, 2010). In this study, direct quotations of the participants were presented under the interpreted codes, allowing readers to compare quotations and interpretations.

\section{Results}

Findings obtained from the data analysis are presented in this part to respond the research questions. Findings of the interviews and observations are demonstrated according to the subproblems of the research. As a result of the interviews and observations made according to the research questions, three themes were reached. These themes are "Assessing Being a Teacher in MC", "Evaluation of Teaching-Learning Process", and "the Problems Faced by Teachers and Their Solutions". The explanations and comments about the themes and their codes are made in the context of the research questions with the subheadings of the themes below.

\subsection{Theme Related to Assessing Being a Teacher in MC}

The $1^{\text {st }}$ sub-problem of the study is "How do classroom teachers working in MC perceive this process?" Findings regarding the problem are presented in Figure 1.

Figure 1

Findings regarding teachers' perception of working in the $M C$

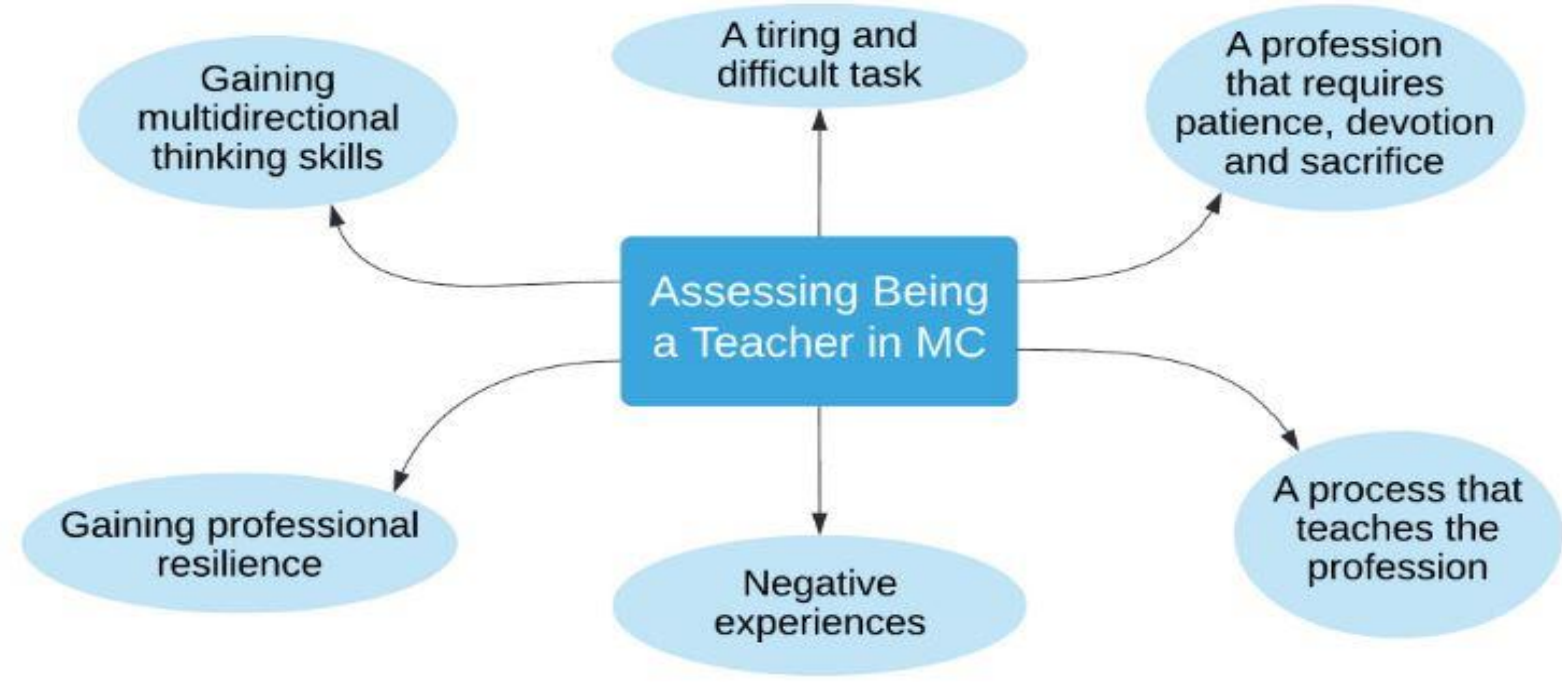

When Figure 1 is examined, it is seen that the "Assessing Being a Teacher in MC" theme emerged from the responses to the "How do classroom teachers working in MC perceive this process?" question.

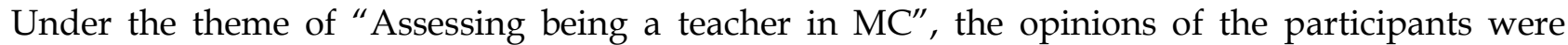
presented by demonstrating the codes in Figure 1. Teachers were united in the idea that the process had improved them in many ways, although they saw working in MC as a general challenging process. They stated that this task makes evaluation a tiring and difficult task, it is a profession that requires patience, dedication and sacrifice, and that it is a process which teaches the teaching profession. The way teachers expressed their opinions on this subject may be clarified through the following samples from teachers' statements. T9: "No matter how bad the conditions 
are, the teacher needs to work devotedly.", T3: "Every classroom teacher should work in MC, which teaches a lot about the profession." T6: "It is tiring but it is nice when one gets its results. However, it is a process that requires patience, devotion and sacrifice." T4: "You experience and see the process that can normally be experienced in 3-4 years within a year." When the statements of the teachers whose opinions were given above were examined, they stated that it is necessary to be patient in this process and that this process provides important experiences. The teachers, who negatively defined working in $\mathrm{MC}$, stated that the process was challenging, decreased motivation, and led to energy loss. Examples of teachers' expressions for the "Negative Experiences" code are presented below:

When I had no teaching experience, working in such a class was quite weary for me. It is also a very tiring job; you cannot deal with anything else. T7.

School and environmental conditions, planning teaching, physical disabilities, etc... You have to deal with all of these, and this situation is challenging us. However, this prepares us better for the process. In addition, education does not only mean teaching a subject at school. You must have information about children living in a village. Education should also be provided to reach children and develop them in the best way possible. That is why it teaches professional thinking in many ways. T5.

When the statements above are examined, it is seen that the teachers emphasized that working in $\mathrm{MC}$ is very tiring because they are busy with many things other than education and these jobs take a lot of time. Some teachers, on the other hand, stated that being a teacher in MC caused them to experience negative psychological conditions such as professional burnout. Examples of teachers' expressions presented are below:

I see this process as the biggest loss in my life. This is because I have to deal with everything except for teaching. Problems of living in a village, endless deficiencies... T2.

This duty takes the concept of patience out of our lives. T10.

If I started at a school in the city center, I would have better feelings. But now, I feel really bad. T1.

When the statements of the teachers whose opinions were given above were examined, they revealed that they did not know what to do because they did not have enough experience, and that this process created impatience and professional burnout. When teachers are observed in terms of the tasks they accomplish other than educational activities, they seem to be engaged in maintenance and cleaning works, allocating time for the school's problems, caring for the parents, listening to them and trying to solve their problems. While coping with the school's problems, some teachers cooperate with the students and their parents and make plans together with them in order to make use of the time well. It was observed that T6 performed school cleaning with the students and collected garbage when the lessons were over. It was found out that T1 cleaned the sinks during the break times and made repairs at the warehouse, used as the boiler room of the school, at the end of the day. Likewise, it was observed that $\mathrm{T} 8$ tried to make minor renovations in the school building and garden by his own efforts and some parents tried to help him in some parts of the work. It was observed that T3 lighted the stove and cleaned it, and it was also seen that he was struggling against some pests such as insects and mice.

\subsection{Theme Related to Evaluation of Teaching-Learning Process}

The $2^{\text {nd }}$ sub-problem of the study is "What are the problems faced by classroom teachers working in MC in planning, implementing and evaluating the teaching-learning process? What solutions do they develop to eliminate these problems?". Findings regarding the problem are presented in Figure 2. 
Figure 2

Findings regarding the problems faced by teachers in-class and their solutions

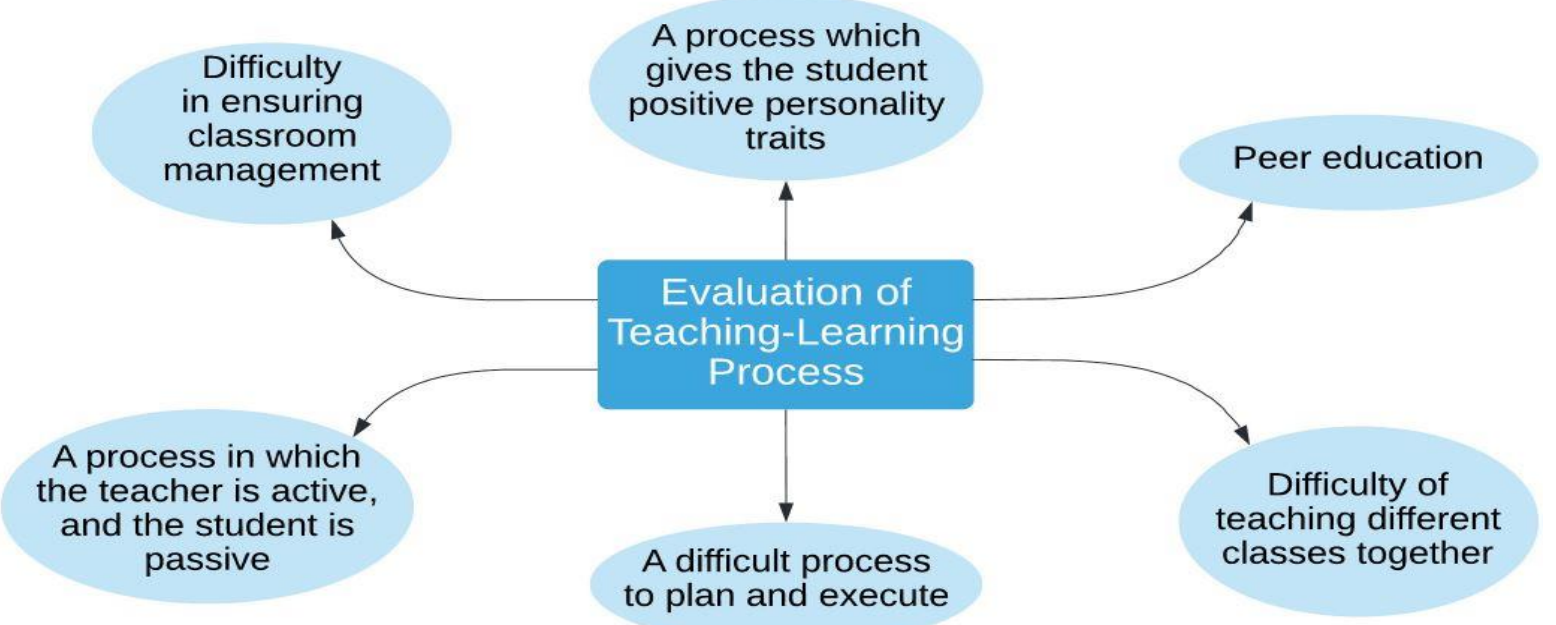

When Figure 2 is examined, it is seen that the theme "Evaluation of Teaching-Learning Process" was determined for the question "What are the problems faced by classroom teachers working in MC in planning, implementing and evaluating the teaching-learning process? What solutions do they develop to eliminate these problems?". Under the theme of "Evaluation of teaching-learning process", most of the teachers expressed similar opinions about the difficulty of teaching different grade levels together and stated that the workload was heavy in the MC. The way teachers expressed their opinions on this subject may be clarified through the following samples from teachers' statements. T9: "I plan the lesson, but that plan remains on paper. I teach four classes together, and it is not possible for all of them to achieve all the outcomes in the plan." T3: "I teach three classes together, and this prevents us from trying new things." T4: "It is very difficult to teach different classes together, because normally three or four teachers would be required to do this job; therefore, one teacher cannot do the whole job." Teachers stated that planning and implementation are difficult processes in joint classrooms. T8: "We cannot plan an activity that will make all grades in the classroom participate. While dealing with one grade, others only wait. That is why the process takes the form of giving assignments to students and carrying out question-answer sessions."

According to the observations, it can be understood that the teachers had difficulties in planning and implementation, they were exhausted and worn out, they lacked technological tools, and they could not use different teaching methods and techniques due to the combination of different grade levels. During the two lesson hours, T9 allocated time only to the first graders, and there was no time for an activity to evaluate students in the other three grades. It was observed that $\mathrm{T} 9$ did not manage the time well and could not arrange the time well among classes. T4, on the other hand, could not carry out activities suitable for demonstration technique due to lack of technological tools. It was observed that $\mathrm{T} 4$ also had difficulty in meeting the time limit, tried to continue the lessons even during break times and was exhausted at the end of the day.

Apart from the negativities encountered, most of the teachers stated that they benefitted from peer education in the process. The opinions of T10 and T2 on this matter are as follows: "I benefit from peer education in this process.", "The upper grades support the lower grade students when they need help, or when I have to deal with different classes." Some of the teachers working in the $\mathrm{MC}$ articulated that the students in these classes matured more quickly, solidarity and cooperation increased in the class, they became tolerant towards the little ones, communication between the students was strong and they could spend time comfortably with each other. In this regard, teachers' opinions are as follows: T6: "In this process, children are able to be a big sister.", T5: "Those in the upper grades can mature early and become a big sister."

The data obtained from the observations supported these findings. It was observed that teachers frequently used peer teaching in this process and this supported positive personality 
development in students. T3 was particularly focused on teaching how to read and write for first graders. The process enabled some students in the 3rd grade to help students who had difficulty in learning. It was observed that he tried to use peer education in the process.

In regard to the difficulties in classroom management, the following statements of T10 and T6 can be given as examples: "Children are not taught about a single subject, I have a heavy workload, and I cannot complete the program in time.", T6: "The number of students who sit together by necessity during lessons is sometimes three or even four. This makes it difficult for me to maintain classroom management."

According to the observations, it can be understood that the teachers have certain problems in relation to classroom management, but they can handle the process. It has been observed that teaching different grade levels together creates difficulties in ensuring classroom management. It was observed that T7 had difficulties especially at the starting and ending times of the lessons, and it was also seen that he could handle the situation during the lesson time. In the classroom of T6, it was observed that the students in homework lessons were working inefficiently, they were quickly distracted, and they were exhibiting undisciplined behaviors. In the classroom of T2, the results of the observations demonstrated that the duration of the lesson was not sufficient, the teacher could not attend to every grade, the groups with homework exhibited maladaptive behaviors and they got quickly distracted. Taking this situation into account, it was observed that the teacher had serious problems in ensuring classroom management.

\subsection{Themes Related to the Problems Faced by Teachers and Their Solutions}

The $3^{\text {rd }}$ sub-problem of the study is "What kind of difficulties do classroom teachers working in MC encounter during the out-of-class process? How do they deal with these problems?" Findings regarding the problem are presented in Figure 3.

Figure 3

Findings regarding the problems faced by teachers out-of-class and their solutions

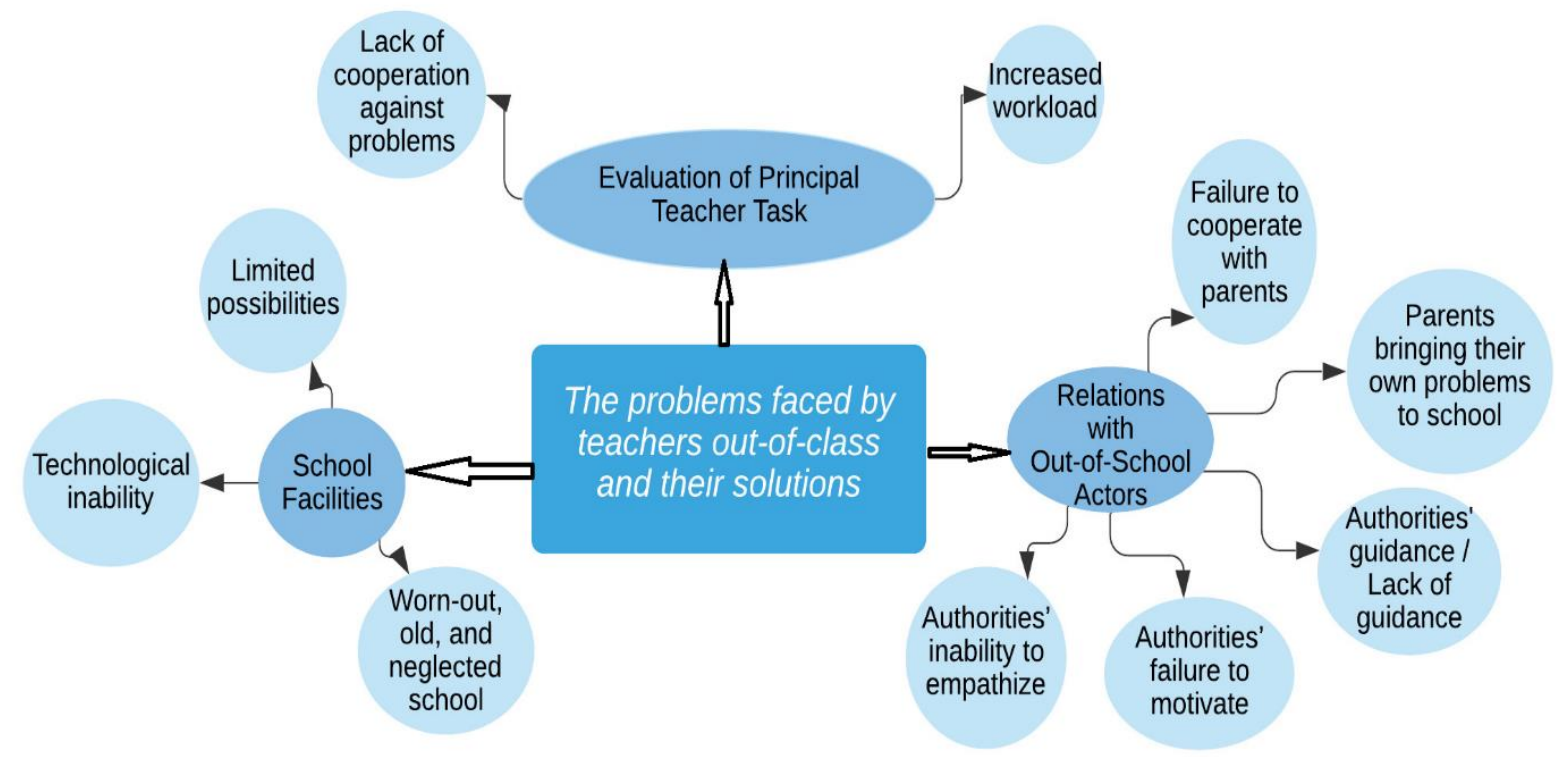

When Figure 3 is examined, it is seen that three themes were determined for the question "What kind of difficulties do classroom teachers working in MC encounter during the out-of-class process? How do they deal with these problems?". These themes are "Evaluation of principal teacher task", "School facilities" and "Relations with out-of-school actors". The findings are presented under each theme.

\subsubsection{Evaluation of principal teacher task}

As presented in Figure 3, the views teachers expressed under the theme "Evaluation of principal teacher task" were "increased workload" and "lack of cooperation against problems". It is 
understood that teachers did not have positive thoughts about the principal teacher task, since these tasks challenged them, and they had to deal with everything except for teaching. Teachers' views on this issue are as follows:

I have to go and complain to the Ministry of National Education. It is already a challenge to teach different classes and we are given an extra responsibility and burden of a principal teacher's task. Naturally, we are very tired. T7.

Both schoolwork and village work are expected from us constantly. T1.

This task imposes administrative tasks and a lot of workload apart from educational activities. I am dealing with all the deficiencies and correspondences of the school. T2.

You are at the same time the principal, the teacher and the janitor, that is, everything of the school. You cannot find anyone to help you with a problem. T3.

The statements of the teachers whose opinions were given above revealed that the principal teacher tasks turned out to be a big burden on them, they had to deal with many things other than teaching, and that their job descriptions were too extensive and therefore their roles in the school were constantly changing. They also emphasized that this situation had a corrosive effect on them and that they were exhausted.

In addition, according to the observations, it is understood that tasks of an authority created an extra workload for teachers, and it was a tiring and challenging task. Formal procedures that involved documents and correspondence, especially within the scope of this task, were observed to occupy a great deal of teachers' times. It was observed that the teachers came to school early in the morning to check whether there was an official document to be answered urgently, and they checked the system in the break times, as well. T9, who was observed in the last two lesson hours of the day, was seen to stay for an extra while in order to deal with correspondences and other official matters at the end of the day. It was observed that T7 checked the outgoing documents frequently during the day, updated some necessary official books, prepared some documents such as student certificates at parents' request, and entered attendance at the end of the day. Similarly, T3 was observed to check the system for any paperwork waiting, first thing in the morning.

\subsubsection{School facilities}

As a result of the analysis, codes of "limited possibilities", "technological inadequacy" and "wornout, old, neglected school" were generated under the theme "School facilities". Teacher statements on this issue are as follows:

There is no restroom in the school, the internet is very unstable, the computers are very old, and the browser is not working. T7.

The building is very old and neglected. We are doing the best we can, together with the janitor. We are constantly having internet problems. T1.

We have a lot of inadequacies, whether it is transportation, communication, or technological conditions and opportunities. T10.

Teachers generally complained that their school was old and neglected. They stated that the facilities provided by the school were extremely insufficient; therefore, they had difficulty in carrying out many things. They also emphasized that the school had deficiencies in terms of technological tools and equipment, it did not have an infrastructure for a stable internet connection, or it was simply not good enough. This situation was also noted in the observations. As an example from the observations, T4 could not carry out activities suitable for demonstration technique due to lack of technological tools.

\subsubsection{Relations with out-of-school actors}

Out-of-school actors in the theme "Relations with out-of-school actors" in Figure 3 are parents of the students, the inspector, district director of National Education and branch manager who visit 
the school for inspection. Codes under this theme are "failure to cooperate with parents", "parents bringing their own problems to school", "authorities' (local and central authorities of Ministry of National Education) guidance / lack of guidance", "authorities' failure to motivate", and "authorities' inability to empathize". The teachers stated about relations with the parents that they were generally respectful, but they were not very interested in the issues about education. In addition, they expressed that they could not cooperate with the parents and sometimes they brought their own problems to school. The opinions of the teachers on this subject are as follows:

I keep in touch with parents and hold meetings. I am generally satisfied with my students' parents, but their support for education is limited. T8.

Villagers are well-intentioned people, and they are trying to support. But sometimes it is possible that they bring problems among themselves to the school or spread rumors that the teacher is close to some of them but distant from others. These affect us both as a teacher and as someone who lives there. T2.

Parents do not come to the school much, they only come when there is a negative situation or complaint. Apart from that, they do not support the problems we experience with the students, the difficulties experienced during the education process, or deficiencies of the school. T6.

The teachers stated that the parents were not helpful. They claimed that they were relatively more helpful in non-educational issues. Other than parents, teachers mostly portrayed their relations with authorities such as inspectors, branch managers, district directors of national education who visited the school. The following statements of teachers came to the fore in this regard:

They rarely come to the school. We are a forgotten school. When they come, they do not provide much benefit. T9.

They usually came and thanked us for existing in these schools. But sometimes, some of them came out and focused on unnecessary details such as the reason why the door or the wall was scratched. There is nothing to motivate us here. T10.

I did not see any benefit coming from authorities. They come up with matters like "Why is this document missing?", "Do you have this report?". They do not come to show a way to improve the situation of the school or the students. T4.

The teachers whose opinions were given above complained about authorities emphasizing the unnecessary details, not providing proper guidance, and not showing an approach that facilitated the process. On the other hand, some teachers expressed that the authorities thanked them for being aware of the process and that such authorities had a guiding role. Expressing her positive opinion, T1 stated the following on this issue: "They try to help when they come, and they guide us on what to do in the process and how."

Considering the results obtained from the observations in a general manner, it was noticed that they supported the results obtained from the interviews. It was observed that the dimensions stated in the observation and the interviews were in consistency, except for one of the themes. The other themes appeared also in the observation. There were not many chances to conduct observations under the theme that was determined as "Relations with out-of-school actors" in the interview findings.

\section{Discussion and Conclusion}

The data collected from the teachers was categorized into three themes based on common and similar characteristics. When looked at these three themes from a holistic viewpoint, it can be seen that the majority of the teachers have negative opinions towards working in MCs. In the light of the findings obtained from the interviews, most of the teachers evaluated this as an exhausting and challenging task and expressed that it incorporated negative experiences and it caused loss of motivation for teachers. Besides, statements as to how teachers lose patience during the process 
and how they go through burnout come to the forefront. These results correspond to the findings of a research on MCs in South Africa, carried out by Taole and Mncube (2012), in terms of shedding light on assessing the profession and showing general deficiencies of these schools and discrepancies resulting from chronical problems, as well as the negative perception that these discrepancies create. Teachers who work in MCs located in the rural and remote areas of South Africa have been observed to complain about unresolvable problems such as not being able to complete the curriculum in time, general and physical deficiencies, etc. Similarly, findings of the current study regarding the MC application coincide greatly with those of a study carried out by Erdem (2015) in terms of not being able to complete the curriculum in time and general deficiencies; those of a research conducted by Gözler (2009) in terms of heavy workload and exhaustion it causes; and those of a study by Kaykanac1 (1993) with regards to chronic problems. Besides, Giannakos and Vlamos (2012) reached the conclusion in their study that schools with MCs located in Greek Islands undergo more challenges than schools in big cities, which also supports the results of this study. Research conducted by UNESCO (1989) in Southeast Asia and Australia demonstrated that MCs face almost the same problems in all the countries of the world. Considering this situation, it can be asserted that the MC application, which is indispensable within an education system, is a solution that incorporates certain problems due to many factors.

On the other hand, in relation to assessing the profession, it has been concluded from the interviews and observations that better results could be obtained when teachers are devoted and patient, thus in this process they practice the profession better and gain professional resilience. Another important result of the study is that teachers improved their planning and multidirectional thinking skills in this process. In their study Erdem et al. (2005) indicated that in an MC, they practiced applying teaching methodology and techniques in the teaching process, assessing and evaluating, using materials, and managing to plan several programs simultaneously. Saqlain (2015) stated in his study that the MC application contributes positively both to the student and the teacher; also, teachers working in such schools gain experience in time management and planning. In addition, while listing the advantages of the MC application, Doğan (2003) highlighted its positive contribution to professional development of teachers. These findings can be said to reflect the positive results of the MC application.

Results related to the teaching-learning process showed that teachers stated that peer education was used the most, and observations showed that teachers received support from upper-class students within the scope of peer education. In a similar manner, Cornish (2006) concluded in her study on MCs located in rural areas of Australia that parents were highly content with the fact that students had been working together with their peers and upper grade students. Likewise, the positive emphasis on peer education in MCs has been underlined by other researchers (e.g. Binbaşığlu, 1999; Erdem, 2015; Summak et. al, 2011). Besides, interviews with teachers indicated that this process contributed to positive personality development of children. It was also concluded from the observations that students improved their sense of solidarity, cooperation and sharing, in addition to becoming more tolerant. This result overlaps with the findings of a research conducted by Veenman (1995), who indicated that students communicated more and mentioned the positive effects of this situation. A similar emphasis on these positive features that are brought by education in a close environment with a small student group has been uncovered by Gözler (2009).

It was highlighted by the teachers that students could not show sufficient participation in the lessons, and planning was highly difficult due to various grade levels working together. When the results of the observations were considered, it was seen that teachers underwent problems about planning the process and carrying out the application. In studies conducted by Aikman and Pridmore (2001), Dursun (2006), and Döş and Sağır (2013), it was emphasized that it creates important teaching problems to have a school structure with MC. It was also seen in the interviews and observations that these results brought along negative student behaviors, and this application put an extra burden on teachers due to lack of physical and technological facilities in the school. 
These coincide with the results of studies by Hargreaves (2001) and Palavan and Göçer (2017), which indicated that students who received education in MCs demonstrated maladaptive behaviors and schools had utterly limited facilities. Also in Little's (2001) study, it was marked that schools with MCs had chronic problems.

In the light of the findings of the research, results on the matters of planning the learningteaching process, problems arising from crowded classrooms and general classroom management problems display great similarities with the findings of the studies carried out by Veenman (1995), Mulryan-Kyne (2007), and Summak et al. (2011). Little (2005) underlined that it was an important problem to have crowded classes and a multigrade environment. A remarkable result drawn from the observations was that despite having certain problems about classroom management, teachers managed to handle the process in general. When related literature was reviewed, it was seen Mulryyan-Kyne (2004) came to the conclusion in related studies that teachers were able to manage several classes effectively.

Teachers who were participants in the current study mostly evaluated the concept of principal teacher task as one with heavy workload and responsibility. Findings obtained from the opinions of participant teachers are in collaboration with the studies in related literature that have similar results (Döş \& Sağır, 2013; Erdem et al., 2005; Kaykanac1, 1993; Mulryan-Kyne, 2007; Palavan \& Göçer, 2017; Taole \& Mncube, 2012). Participant teachers stated that dealing with both educational processes and paperwork as well as taking care of physical problems of the school improved them in many ways; however, this process exhausted and challenged them. It was also concluded in the observations that teachers having the principal's duty dealt with cleaning toilets and heating and came to the school early in the morning or stayed late after the lessons in order to do paperwork. The results obtained by Cornish (2006) in Australia, by McEwan (2008) in South America, by Taole and Mncube (2012) in South Africa by Giannakos and Vlamos (2012) in Greece, and by Erdem (2015) in Turkey are in concordance with the findings of the present research, since these studies found out that teachers had never undertaken such responsibilities before and did not receive enough guidance, it was sometimes impossible to give lessons and deal with paperwork at the same time, constant inconveniences occurred, and it was an exhausting duty despite being a different experience professionally.

When it came to the results about the facilities provided by schools with MCs, participant teachers were in agreement in the opinion that these schools were incompetent in terms of infrastructure, physical facilities, and technological equipment. Results that support teacher opinions were obtained in the observations, as well. These findings coincide greatly with those obtained by Dursun (2006) and Little (2005), which can be expressed as follows: (1) MCs lack basic technological equipment and course materials, (2) alternative activities and materials for making lessons with homework more effective are almost non-existent, (3) teacher age conditions are inadequate, (4) school gardens are generally neglected, (5) problems may arise even in meeting vital needs such as heating and maintenance, (6) some schools do not even have restrooms or some schools with restrooms lack water installation.

After examining the findings obtained under the theme of "relations with out-of-school actors", it was concluded that teachers were left alone by the villagers and parents in educational matters, whereas they collaborated with teachers in other issues. These problems that teachers experience with the environment have been supported by the results of the studies carried out by Dursun (2006), Gözler (2009), and Döş and Sağır (2013). This finding is partly in agreement with the results achieved by Cornish (2006) in Australia and McEwan (2008) in South America that teachers' having basic knowledge about the culture of where they work and making decisions in the light of this knowledge have great contributions to the cooperation between school and environment, and that it is possible to mitigate the disadvantages of schools with MCs to a certain degree with the help of active cooperation.

In terms of inspection dimension, it has been established that inspections were rarely conducted, teachers were not provided with sufficient guidance, teachers felt that they were left 
alone, and necessary solutions were not generated for the ongoing problems during the inspections. In accordance with these findings, Palavan and Göçer (2017) carried out a research which revealed that branch managers or inspectors from Ministry of National Education, who visited schools for inspection, made evaluations without taking into account the current conditions of the school, they were far from using constructive wording during inspection, and a communication gap occurred after the inspection. Classroom teachers working in MCs undergo similar problems throughout the world, in terms of inspection and lack of guidance (Little, 2001; UNESCO, 1989).

Based on the research results, the following suggestions have been developed for the teachers:

- In this process, classroom teachers' acquaintance with the village people and culture will facilitate their adaptation to the process. They will also be able to meet people from the village with whom they can cooperate in finding solutions to certain problems.

- Classroom teachers working in MC can carry out student recognition studies about both their academic and personal characteristics and prepare specialized plans and programs accordingly.

Additionally, the following suggestions have been addressed for the policy makers:

- Certain social activities can be organized to motivate teachers working in MC. In addition, if better accommodation opportunities are offered for a better fee, these teachers might enjoy their duties more.

- A separate curriculum can be prepared for MC. In this way, the burden of planning undertaken by teachers can be eased and neglecting some groups in the classroom can be prevented.

- Teachers working in these schools can develop effective communication skills via trainings on the culture of the place where they work in order to strengthen the bond among the school, village environment and parents.

- Most of the teachers in these classes do not know much about the operation of formal procedures. Therefore, an application should be developed to train them for the principal teacher tasks. Experienced managers can manage the process better this way, if 2 or 3 weeks of internshiplike training can be provided.

- Teachers working in these schools can be offered more effective guidance and more constructive supervision services.

Finally, the paper has some certain limitations to be considered when evaluating the results. First, the research was conducted with a small number of participants. Second, working with teachers in different provinces and districts could offer different problems and different perspectives.

\section{References}

Aikman, S., \& Pridmore, P. (2001). Multigrade schooling in 'remote'areas of Vietnam. International Journal of Educational Development, 21(6), 521-536. http:// doi.org/10.1016/S0738-0593(01)00012-8

Bilir, A. (2008). Teacher and educational fact at multigraded classrooms rural primary schools. Ankara University Journal of Faculty of Educational Sciences, 41(2), 1-22. http://doi.org/10.1501/Egifak_0000001130

Binbaşığlu, C. (1999). Birleştirilmiş sınıflarda öğretim [Teaching in multigrade classrooms]. Anı.

Birch, I., \& Lally, M. (1995). Multigrade teaching in primary schools. UNESCO Principal Regional Office for Asia and the Pacific.

Braun, V. \& Clarke, V. (2014) What can "thematic analysis" offer health and wellbeing researchers?. International Journal of Qualitative Studies on Health and Well-being, 9(1), 26512. http://doi.org/10.3402/qhw.v9.26152

Ciesielska M., Boström K.W., \& Öhlander M. (2018) Observation methods. In Ciesielska M., Jemielniak D. (Eds.), Qualitative methodologies in organization studies (pp. 33-52). Palgrave Macmillan. https://doi.org/10.1007/978-3-319-65442-3_2

Cohen, L., Manion, L., \& Morrison, K. (2005). Research methods in education. Routledge Falmer.

Cornish, L. (2006). parents view of composite classes in an Australian primary school. The Australian Educational Researcher, 33(2), 123-142. 
Creswell, J.W. 2007. Qualitative inquiry and research design: Choosing among five approaches (2nd ed.). Thousand Oaks, CA: Sage.

Doğan, A. R. (2003). Birleştirilmiş sınıflarda eğitim öğretim [Education in multigrade classrooms]. Uzun Pub.

Döş, İ.\& Sağır, M. (2013). Manegement problems of elementary schools with multi-grade classes. Atatürk University Journal of Social Sciences Institute, 17(2), 237-250.

Dursun, F. (2006). Birleştirilmiş sınfflarda eğitim sorunları ve çözüm önerileri [Educational problems and solutions in multi-grade classrooms]. Journal of Social sciences Research, 2, 33-57.

Erdem, A.R. (2015). Birleştirilmiş sınıflarda öğretim. [Instruction in multigrade classrooms]. Ankara: Anı Yayıncilik.

Erdem, A.R., Kamac1, S., Aydemir, T. (2005). The problems of the primary school teachers in charge of teaching and training united classrooms: Denizli case. Journal of Theory and Practice in Education, 1(1-2), 313.

Giannakos, M., \& Vlamos, P. (2012). Using educational webcasts in small multigrade schools of isolated islands. International Journal of Education and Development using ICT, 8(2), 131-141.

Gözler, A. (2009). The management problems experienced in schools with multigrade classes. [Unpublished dissertation]. Firat University, Elazı

Hargreaves, E. (2001). Assessment for learning in the multigrade classroom. International Journal of Educational Development, 21(6), 553-560. http://doi.org/10.1016/S0738-0593(01)00015-3

Johnson, B., \& Christensen, L. (2004). Educational research: quantitative, qualitative and mixed approaches. Pearson Education.

Jordaan, V., \& Joubert, J. (2007). Training of teachers in poor rural areas through a multigrade intervention to achieve millennium development goals: Our experience of using ODL as a tool for building capacity and what lessons can be learned? Cape Peninsula University of Technology.

Joubert, J. (2010). Multi-grade teaching in South Africa. Common Wealth Education Online.

Joyce, T. M. (2014). Quality basic education for all: Challenges in multi-grade teaching in rural schools. Mediterranean Journal of Social Sciences, 5(1), 531. http://doi.org/10.5901/mjss.2014.v5n1p531

Kaykanacı, M. (1993). Birleştirilmiş sımıfl köy ilkokullarında görevli müdür yetkili öğretmenlerin yönetimle ilgili problemleri (Kastamonu ili örneği) [Management problems of teachers authorized by principals in village primary schools with combined classrooms (Kastamonu case)] [Unpublished master thesis]. Gazi Universdity, Ankara.

Network for Change in Village Schools (KODA), (2019). 2018-2019 Faaliyet Raporu [2018-2019 Annual Report]. https:/ /4carma.com/sites/default/files/annual_report/Koda\%202018\%202019.pdf

Kohn, L. T. (1997). Methods in case study analysis. The Center for Studying Health System Change.

Köksal, K. 2005. Birleştirilmiş sınıflarda öğretim [Teaching in multigrade classrooms]. Pegem Akademi.

Lincoln, Y.S., \& Guba, E.G. (1985). Naturalistic inquiry. Sage.

Little, A. W. (2001). Multigrade teaching: towards an international research and policy agenda. International Journal of Educational Development, 21(6), 481-497. http://doi.org/10.1016/S0738-0593(01)00011-6

Little, A. W. (2005). Learning and teaching in multigrade settings. Unpublished paper prepared for the UNESCO. https://pdfs.semanticscholar.org/2bd5/7b8bd2754ea10dfbd50d3d4df6d17fc5c79e.pdf

Little, A. W. (2006). Education for all and multigrade teaching. Springer. http:// doi.org/10.1007/1-4020-4591-3

McEwan, P. J. (2008). Evaluating multigrade school reform in Latin America. Comparative Education, 44(4), 465-483. http:// doi.org/10.1080/03050060802481504

Merriam, S. B., \& Tisdell, E. J. (2015). Qualitative research: A guide to design and implementation. John Wiley \& Sons.

Miles, M.B., \& Huberman, A.M. (1994). Qualitative data analysis: A sourcebook of new materials. Sage.

Miller, A.B. (1991). A review of the qualitative research on.multigrade instruction. Journal of Research in Rural Education, 7(2), 3-12.

Mulryan-Kyne, C. (2004). Teaching and learning in multigrade classrooms: What teachers say. The Irish Journal of Education, 35, 5-19.

Mulryan-Kyne, C. (2007). The preparation of teachers for multigrade teaching. Teaching and Teacher Education, 23(4), 501-514. http://doi.org/10.1016/j.tate.2006.12.003

Nawab, A., \& Baig, S. R. (2011). The possibilities and challenges of multigrade teaching in rural Pakistan. International Journal of Business and Social Science, 2(15), 166.

Neuman, W. L., \& Robson, K. (2014). Basics of social research. Pearson.

Palavan, Ö., \& Göçer, V. (2017). Problems Faced by the Classroom Teachers in Multigrade Classes (A Case in Malatya Province). Kirıkkale University Journal of Social Sciences, 7(2), 69-96. 
Ocakc1, E. \& Samanc1, O. (2019). Investigation of the class management qualifications and the views of multigrade classroom teachers about class. Abant İzet Baysal University Journal of Faculty of Education, 19(2), 604-620. https:// doi.org/10.17240/aibuefd.2019.19.46660-473991

Keser Özmantar, Z. \& Civelek, Ş. (2017). "Principal Authorized Teacher" practice from the perspectives of in- and pre-service primary teachers. Mersin University Journal of the Faculty of Education, 13(1), 323-347 . http:/ / doi.org/10.17860/mersinefd.306016

Patton, M. Q. (2014). Qualitative research $\mathcal{E}$ evaluation methods: Integrating theory and practice. Sage.

Psacharopoulos, G., Rojas, C., \& Velez, E. (1993). Achievement evaluation of Colombia's" Escuela Nueva": Is multigrade the answer?. Comparative Education Review, 37(3), 263-276. http://doi.org/10.1086/447190

Rowley Jr, S. D., \& Nielsen, H. D. (2014). School and classroom organization in the periphery: The assets of multigrade teaching. In H. D. Nielsen \& W. K. Cummings (Eds.), Quality education for all: Communityoriented approaches (pp. 193-222). Routledge.

Saqlain, N. (2015). A comprehensive look at multi-age education. Journal of Educational and Social Research, 5(2), 285-290. http://doi.org/10.5901/jesr.2015.v5n2p285

Silverman, D. (2010). Doing qualitative research. Sage.

Summak, M.S., Summak A.E.G., \& Gelebek, M.S. (2011). Problems encountered in multi-grade classes and teachers' suggestions for possible solutions (A case study in Kilis province). Gaziantep University Journal of Social Sciences, 10(3), 1221-1238.

Şahin, C. (2010). Birleştirilmiş siniflara ilişkin temel bilgiler [Basic knowledge regarding multigrade classrooms]. In Ç. Şahin (Ed).), Birleştirilmiş sınıflarda öğretim [Teaching in multigrade classrooms]. (pp. 230). Pegem Akademi.

Taole, M., \& Mncube, V. S. (2012). Multi-grade teaching and quality of education in South African rural schools: Educators' experiences. Studies of Tribes and Tribals, 10(2), 151-162. http:// doi.org/10.1080/0972639X.2012.11886653

Titus, T. P. (2004). "The implementation of multigrade teaching in rural schools in the keetmanshoop eetmanshoop education region: leadership and management challenges." [Unpublished master thesis]. Rhodes University Department of Education, South Africa.

Provincial Directorate of National Education [Tokat]. (2015). Birleştirilmiş Simfflarda Öğretimin Niteliği, Sorunları ve Çözüm Önerileri Çalıştayı Raporu [Quality of Teaching in Multigrade Classrooms, Problems and Solution Offers Report]. https://tokat.meb.gov.tr/meb_iys_dosyalar/2016_07/01105114_tokat_kitap_birlastirilmis_siniflar_08_06 2016.pdf

UNESCO. (1989). Multigrade teaching in single teacher primay schools. The UNESCO Principal Regional Office for Asia and The Pacific.

Veenman, S. (1995). Cognitive and noncognitive effects of multigrade and multi-age classes: A best-evidence synthesis. Review of educational research, 65(4), 319-381. http:// doi.org/10.3102/00346543065004319

Yıldız, M. \& Köksal, K. (2009). An assesmet of teacher's views about multigrade classes implementation. Kastamonu Education Journal, 17(1), 1-14.

Yin, R. K. (2009). Case study research: design and methods (4th ed.). Sage. 